\title{
Variation in Rhizobium leguminosarum biovar trifolii Sym Plasmids and the Association with Effectiveness of Nitrogen Fixation
}

\author{
By STEPHEN P. HARRISON, ${ }^{1,2}$ D. GARETH JONES, ${ }^{1 *}$ PETRA H. D. \\ SCHÜNMANN, ${ }^{1}$ JOHN W. FORSTER ${ }^{1}$ AND J. PETER W. YOUNG ${ }^{2}$ \\ ${ }^{1}$ Department of Agricultural Botany, University College of Wales, Aberystwyth SY23 3DD, UK \\ ${ }^{2}$ The John Innes Institute, Norwich NR4 7UH, UK
}

(Received 17 February 1988; revised 23 June 1988)

\begin{abstract}
A number of strains of Rhizobium leguminosarum biovar trifolii were examined for variation in Sym plasmid size and number, using an $R$. leguminosarum nif $A /$ nod probe. Size variation was great and, in a large proportion of strains, multiple Sym plasmids were observed. A probe containing a repeated sequence (RtRS) incorporating the nifH promoter, reported to be specifically found on the Sym plasmid of this biovar, was used to determine whether Sym plasmids were of trifolii origin. This probe did not bind to all Sym plasmids identified by the nifA/nod probe and some isolates were suspected of being inter-biovar hybrids. The RtRS probe was also used to test certain isolates for DNA homology to the nif $H$ promoter region. Many strains possessed commonly occurring co-migrating fragments that hybridized to this probe. Beyond this basic relatedness, greater variation in fragment number and size existed, allowing differentiation of seemingly closely related strains. Strains carrying greater amounts of symbiotic DNA in the form of multiple Sym plasmids or a greater number of hybridizing fragments were less effective in fixing nitrogen.
\end{abstract}

\section{INTRODUCTION}

The localization and close linkage of the genes governing the properties of nodulation and nitrogen fixation on a large plasmid (the Sym plasmid) have been well documented for the recently designated biovars (Jordan, 1984) of the species Rhizobium leguminosarum (Nuti et al., 1979; Ruvkun \& Ausubel, 1980; Hombrecher et al., 1981; Hooykaas et al., 1981; Downie et al., 1983; Schofield et al., 1983). Differences in size of Sym plasmids within $R$. leguminosarum have been noted for small samples of isolates (Hombrecher et al., 1981; Krol et al., 1982). The presence of certain genes contained on Sym plasmids of the same biovar has also been shown to vary (Brewin et al., 1980; Hirsch et al., 1980; Gotz et al., 1985). In one case, (Wang et al., 1986), two Sym plasmids were found in a single indigenous isolate of $R$. leguminosarum biovar trifolii.

The occurrence of multiple Sym plasmids conferring cross-infectivity of hosts has not yet been reported for indigenous strains of $\boldsymbol{R}$. leguminosarum and, from work done on hybrid strains, it has been indicated that such plasmids would not be likely to exist together as functional symbiosis-determining units (Djordevic et al., 1982; Christensen \& Schubert, 1983; Wang et al., 1986) due to effects exerted by the host plant. However, the possibility of two Sym plasmids coexisting in the same strain, albeit with the penalty of reduced nitrogen fixation and/or nodulation in potential hosts cannot be overlooked when considering a large, natural population.

Despite these intra- and inter-biovar differences, a high degree of conservation of certain symbiotically important genes within the biovar trifolii of $R$. leguminosarum (Scott et al., 1983; Watson \& Schofield, 1985) and the species $R$. meliloti (Better et al., 1983) has been shown to exist

Abbreviation: RtRS, Rhizobium trifolii repeated sequence.

$0001-4712$ (C) 1988 SGM 
in the form of repeated sequences. In $R$. leguminosarum biovar trifolii this sequence constitutes a reiteration of the nifHDK promoter region and in some cases an additional reiteration of the $\mathrm{N}$-terminal end of the nif $H$ gene and was designated RtRS ( $R$. trifolii Repeated Sequence) (Watson \& Schofield, 1985).

To quantify Sym plasmid variation between naturally occurring isolates of $R$. leguminosarum biovar trifolii, we identified these plasmids in a number of strains of $\mathrm{UK}$ and international origin using a nif/nod probe. In view of the complications that arise when two Sym plasmids are present in the same strain we were particularly interested in the number of naturally occurring strains containing multiple Sym plasmids. In addition, an RtRS probe was used to examine DNA variation through hybridization to restriction fragments. The same probe was also used to indicate non-biovar trifolii Sym plasmids by virtue of absence of hybridization. We further investigated the effects of these genetic characteristics on the effectiveness of nitrogen fixation as indicated by dry matter production in a white clover (Trifolium repens) macrosymbiont.

\section{METHODS}

Rhizobium strains. Forty-seven isolates of $R$. leguminosarum biovar trifolii were considered in this investigation, although not all were used in each analysis. Twenty strains were kindly supplied to us from other institutes and the remainder were isolated at UCW, Aberystwyth, from indigenous populations of UK soils (Table 1). All isolates were examined for plasmid profile and homology of plasmids to a nif/nod probe (pIJ1085), and a biovar trifolii Sym plasmid-specific probe (pRt722). Thirty-one strains, including the ones acquired from other workers, were tested for symbiotic effectiveness, and twenty-four of these were analysed for DNA homology with an RtRS sequence housed on pRt722. All strains were repeatedly streaked until the purity of the culture was ensured.

Table 1. Strains of R. leguminosarum biovar trifolii utilized in this study, together with the number and approximate sizes of the plasmids of each strain

Plasmids hybridizing with the pIJ1085 and the pRt722 probes are shown in bold. $a$, Plasmids hybridizing with pIJ1085 only; $b$, plasmids hybridizing with pRt722 only ; $c$, thick bands, possibly representing co-migrating plasmids.

\begin{tabular}{|c|c|}
\hline Strain/origin & Size of plasmids $(\mathrm{kb})$ \\
\hline $\begin{array}{l}\text { PDDCC } 2153 \\
\text { NZ }\end{array}$ & $600,356,199,188$ \\
\hline $\begin{array}{l}\text { PDDCC } 2668 \text { (Derivative of PDDCC 2153) } \\
\text { NZ }\end{array}$ & $600,356,199,188$ \\
\hline $\begin{array}{l}\text { PDDCC } 2666 \\
\text { NZ }\end{array}$ & $600,356,199,188$ \\
\hline $\begin{array}{l}\text { PDDCC } 2669 \\
\text { NZ }\end{array}$ & $500,313,238,171,134^{b}$ \\
\hline $\begin{array}{l}\text { PDDCC } 2641 \\
\text { NZ }\end{array}$ & $500,313,171$ \\
\hline $\begin{array}{l}\text { PDDCC } 5065 \\
\text { NZ }\end{array}$ & $500,313,238,199,188$ \\
\hline $\begin{array}{l}\text { PDDCC } 4337 \\
\text { NZ }\end{array}$ & $500,278,199,171$ \\
\hline $\begin{array}{l}\text { PDDCC } 1306 \\
\text { NZ }\end{array}$ & $500,313,256$ \\
\hline $\begin{array}{l}\text { PDDCC } 2163 \\
\text { NZ }\end{array}$ & $500,219,147$ \\
\hline $\begin{array}{l}\text { PDDCC } 2118 \\
\text { Australia }\end{array}$ & $500,418,313$ \\
\hline $\begin{array}{l}\text { 162S7a } \\
\text { Kentucky, USA }\end{array}$ & $500,278,188,81$ \\
\hline $\begin{array}{l}162 \mathrm{P} 17 \\
\text { Wisconsin, USA }\end{array}$ & $550,278,219$ \\
\hline $\begin{array}{l}\text { 162E7 } \\
\text { California, USA }\end{array}$ & $356,313,219$ \\
\hline $\begin{array}{l}162 \text { P30 } \\
\text { USA }\end{array}$ & $550,278,219$ \\
\hline $\begin{array}{l}162 \times 7 a \\
\text { USA }\end{array}$ & $500,313,219$ \\
\hline
\end{tabular}


Table 1. Continued

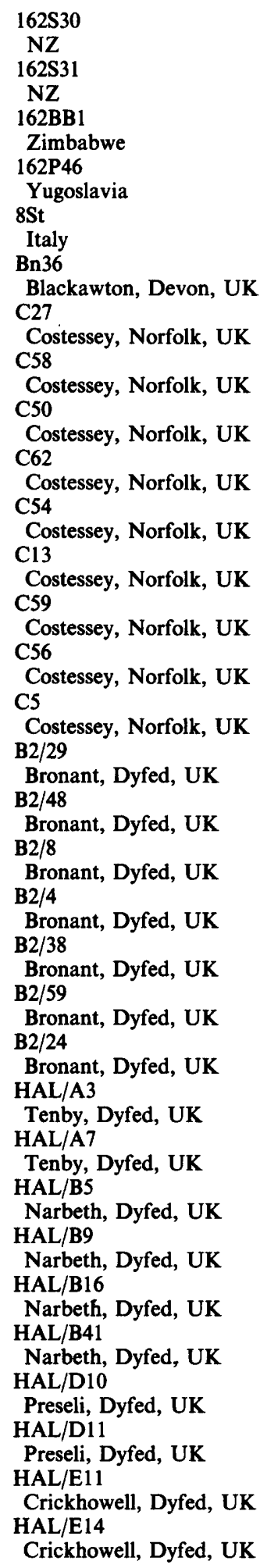

$313,278,256,238,159$

$313,278,256,238,159$

$500,278,188$

$418,278,188$

$313,219,188,147,111$

$418,256,159,88$

$>600,356,219$

$>600,550,356,188,119,95,88$

$>600,500,313,171,111^{a}, 88$

$>600,550,256$

$>600,550,278,219$

$>600,550,238$

$600,462,278,219,147$

$600,500,462,278^{a}, 199$

$550,462,219,188,147$

$>600,500,418,313$

$>600,500,462,418^{a}, 313,256^{b}, 238,171,147,127$

$>600,500,462,418^{a}, 313,256^{b}, 238,171,147,127$

$>600,462,356,278,256^{b}, 199$

$550,462,356,313,256,199,108^{b}, 71,56$

$>600,>600,462,256^{c}$

$>600,>600,462,256^{c}$

$462^{c}, 238,171$

418, 356, 219

$462,313,256,219,171,147,108,56$

$462,313,256,219,171,147,108,56$

$462,313,256,219,171,147,108,56$

$462,313,238,171,119,78,46$

$462,256,171,90$

$462,278,238,219,171,134$

$462,418,238^{c}$

$356,256,219,159$ 
Table 2. Plasmids used for standardization of strain profiles

\begin{tabular}{|c|c|c|}
\hline Plasmid & Size/characteristics & Source/reference \\
\hline $\begin{array}{l}\text { Cam } \\
\text { PAtc58 } \\
\text { PTiC58 } \\
\text { R27 } \\
\text { R64 } \\
\text { R1 } \\
\text { N3 } \\
\text { R6K }\end{array}$ & $\begin{array}{l}500 \mathrm{~kb} ; \text { from Pseudomonas putida } \mathrm{ClB} \\
418 \mathrm{~kb} ; \text { from Agrobacterium tumefaciens } \mathrm{C} 58 \\
199 \mathrm{~kb} ; \text { from } \text { A. tumefaciens } \mathrm{C} 58 \\
171 \mathrm{~kb} \\
111 \mathrm{~kb} \\
95 \mathrm{~kb} \\
51 \mathrm{~kb} \\
40 \mathrm{~kb}\end{array}$ & $\begin{array}{l}\text { D. J. Hopper } \\
\text { van Larebeke et al. (1974) from C. I. Kado }\end{array}$ \\
\hline
\end{tabular}

Testing of strains for effectiveness. Seeds of the white clover (Trifolium repens cv. Huia) were surface sterilized in a solution of $20 \%(\mathrm{v} / \mathrm{v})$ sodium hypochlorite, rinsed thoroughly in sterile distilled water and germinated on sterile water agar. The resulting seedlings were transferred singly to slopes of sterile nitrogen-free nutrient agar (Jensen, 1942) when they were inoculated with $1 \mathrm{ml}$ of the appropriate rhizobial cultures, which had been grown in PA medium (Hirsch et al., 1980) and diluted to the correct concentration with sterile quarter-strength nitrogen-free nutrient solution (Jensen, 1942). Twenty plants per treatment were grown in a growth cabinet for 6 weeks at $16^{\circ} \mathrm{C}$, $16 \mathrm{~h}$ light, then they were oven-dried for $48 \mathrm{~h}$ at $60^{\circ} \mathrm{C}$ and their dry weights determined.

Plasmid analysis and preparation of gels for blotting. Strains were grown in PA media overnight (to a concentration of approx. $10^{7}$ cells $\mathrm{ml}^{-1}$ ) following inoculation with actively growing culture. Rhizobial cell lysis and the electrophoretic method were by slight modification of the method of Eckhardt (1978) described by Hirsch (P. R. Hirsch, personal communication). Cell culture $(1 \mathrm{ml})$ was centrifuged and to the pellet was added $50 \mu \mathrm{l}$ of lysis mix ( $1 \mathrm{mg}$ lysozyme $\mathrm{ml}^{-1}, 1$ unit RNAase $\mathrm{ml}^{-1}$ in $25 \%, \mathrm{w} / \mathrm{v}$, sucrose and $0.025 \mathrm{M}$-Tris/HCl). This mixture was immediately transferred to the sample wells of a $0.65 \%(\mathrm{w} / \mathrm{v})$ agarose gel; a single wide well containing $0.4 \%(\mathrm{w} / \mathrm{v})$ agarose and $1 \%(\mathrm{w} / \mathrm{v})$ SDS was incorporated behind these wells. A BRL horizontal gel kit was used to run gels at $150 \mathrm{~V}$ for $4 \mathrm{~h}$ in Tris/borate buffer (pH 8.3). Gels were stained in a solution of $1 \mu \mathrm{g}$ ethidium bromide $\mathrm{ml}^{-1}$ for 40 min.

Plasmid size was determined by calibration against the relative mobilities of a number of plasmids of known size (Table 2).

DNA was Southern blotted from gels to Zetaprobe nylon membranes (Bio-Rad) which facilitate multihybridizations and allow the use of more than one probe.

Preparation of DNA for restriction analysis. Pelleted cells were resuspended in $2 \%(\mathrm{v} / \mathrm{v})$ sarcosyl in Tris/EDTA (TE) buffer, digested in $5 \mathrm{mg}$ pronase $\mathrm{ml}^{-1}$ (Sigma, type XIV) at $37^{\circ} \mathrm{C}$ for $1 \mathrm{~h}$ and the resulting DNA was ethanol precipitated at $-20^{\circ} \mathrm{C}$. The mixture was then treated with $20 \mu \mathrm{g} R$ RAase $\mathrm{ml}^{-1}$ for $30 \mathrm{~min}$ at $37^{\circ} \mathrm{C}$, phenol/chloroform extracted, and washed with equal volumes of diethyl ether. Finally, a second DNA precipitation with ethanol was done.

The extracted DNAs were treated with $E c o$ RI, run overnight on $0.65 \%(\mathrm{w} / \mathrm{v})$ agarose gels at $30 \mathrm{~V}$ and blotted to Zetaprobe membranes. HindIII-treated $\lambda$ DNA was used as a molecular mass standard.

Description of probes and preparation of probe DNA. pIJ1085 (Downie et al., 1983) contains nod and nifA-like DNA from pRL1JI (Johnston et al., 1978) cloned into the cosmid pLAFR1. pRt722 is related to the plasmid pRt642 containing an RtRS described by Watson \& Schofield (1985) and was constructed by cloning an approximately $250 \mathrm{bp} \mathrm{ClaI-AvaI}$ fragment, incorporating a highly conserved, repeated sequence from the nif $H$ promoter region of $R$. leguminosarum biovar trifolii ANU843, into pUC18 (Norrander et al., 1983).

Pelleted cells were washed in $\mathrm{M} 9$ buffer and resuspended in lysis $\operatorname{mix}(50 \mathrm{mM}$-Tris $\mathrm{HCl}, \mathrm{pH} 8.0 ; 10 \mathrm{mM}-\mathrm{EDTA}$; $9 \mathrm{mg}$ glucose $\mathrm{ml}^{-1} ; 5 \mathrm{mg}$ lysozyme $\mathrm{ml}^{-1}$ ). The mixture was then treated with $1 \%(\mathrm{w} / \mathrm{v}) \mathrm{SDS}$ in $0 \cdot 2 \mathrm{M}-\mathrm{NaOH}$, mixed with cold 5 M-potassium acetate, pH 4.8, spun and mixed with propan-2-ol. Following a further spin the pellet was dissolved in water and to this was added $5 \mathrm{M}-\mathrm{LiCl} / 50 \mathrm{mM}$-MOPS. Ethanol was added to the resulting supernatant and the precipitate was treated with $1 \mathrm{mg}$ RNAase $A \mathrm{ml}^{-1}$ plus $500 \mathrm{U}$ RNAase $\mathrm{T} 1 \mathrm{ml}^{-1}$ at $37^{\circ} \mathrm{C}$ for $10 \mathrm{~min}$. After digestion with proteinase $\mathrm{K}$ for $10 \mathrm{~min}$ at $37^{\circ} \mathrm{C}, 1 \mathrm{M}$-sodium acetate/0.5 M-MOPS solution and propan-2-ol were added. Finally the pellet was resuspended in TE, extracted with chloroform and the aqueous phase was ethanolprecipitated at $-20^{\circ} \mathrm{C}$ in the presence of $5 \mathrm{M}-\mathrm{NaCl}$.

The probe DNA was labelled, using a BRL nick-translation kit, with $\left[\alpha^{-32}\right] \mathrm{dCTP}$ and was separated from the unincorporated nucleotides by ethanol precipitation.

Hybridization of filters with probes. The filters with the bound plasmid DNA were first hybridized with the nif probe for $8 \mathrm{~h}$ at $68^{\circ} \mathrm{C}$. Prior to autoradiography they were washed twice in $2 \times \mathrm{SSC} / 1 \%(\mathrm{w} / \mathrm{v})$ SDS and twice in $0.2 \times \mathrm{SSC} / 1 \%(\mathrm{w} / \mathrm{v}) \mathrm{SDS}$ for $15 \mathrm{~min}$ at $55^{\circ} \mathrm{C}(1 \times \mathrm{SSC}$ is $0.15 \mathrm{M}-\mathrm{NaCl}, 0.015 \mathrm{M}$-trisodium citrate, $\mathrm{pH} 7.0)$. Following autoradiography at $-70^{\circ} \mathrm{C}$ against Kodak XAR film using twin intensifying screens, the membranes were washed in boiling $0.1 \times \mathrm{SSC} / 0.5 \%(\mathrm{w} / \mathrm{v}) \mathrm{SDS}$ to allow re-use. 
Hybridization with the pRt 722 probe was done as above although the washes following hybridization were at $65^{\circ} \mathrm{C}$ to achieve higher stringency.

The restriction fragments were hybridized only with the pRt 722 probe and the method was as above.

\section{RESULTS AND DISCUSSION}

\section{The size and number of Sym plasmids present in each isolate}

The isolates of $R$. leguminosarum biovar trifolii examined exhibited much variation in plasmid profile, ranging from 46 to $>600 \mathrm{~kb}$ in size and 3 to 10 per strain in number (Table 1). The pIJ1085 probe was used to identify Sym plasmids within the various isolates, revealing a size range of $111-418 \mathrm{~kb}$ with a mean of $224 \mathrm{~kb}$ (Table 1, Fig. 1). The estimated sizes of plasmids may seem to be 'over accurate' and not to allow for error, but the differences, however small, that did occur between similarly sized plasmids were real. Such small variation should be illustrated and not be obscured by rounding-up of size values. The number of Sym plasmids per isolate varied from one to three (Table 1). These results corroborate the report of Sym plasmid size differences by Hombrecher et al. (1981) and Krol et al. (1982) in the biovar viceae. A number of explanations can be put forward to account for this diversity. The instability and tendency of Sym plasmids to delete under particular conditions has been recognized by Zurkowski (1982); presumably conditions within natural environments may occasionally favour such deletions, thereby generating size differences in indigenous Sym plasmids. Ronson \& Scott (1983) showed the readiness of Sym plasmids to recombine with cryptic plasmids, which could result in a Sym plasmid carrying a large proportion of non-symbiotic DNA. Certain genes are not universally found on the Sym plasmids of all strains (Brewin et al., 1980; Hirsch et al., 1980; Gotz et al., 1985 ) and, although variation in single genes may not affect any significant differences in Sym plasmid size, the combined variability might.

Although variable in size, Sym plasmids did exhibit a certain degree of size homology in falling into clusters of similar magnitude and a common feature between strains was that the Sym plasmid was never the largest plasmid and was frequently the smallest.

Multiple Sym plasmids occurred in 12 of 47 strains. In the case of C50, three Sym plasmids were observed (Table 1, Fig. $2 a$ ). This shows that the finding of a multiple Sym plasmid isolate by Wang et al. (1986) was not an unusual occurrence. Isolates with a high number of plasmids can be seen, in general, to have multiple Sym plasmids (Table 1) and there was a positive relationship between the total number of plasmids and the number of Sym plasmids $(r=0.628$; $P<0.001$ ). From Thurman et al. (1985) and from our unpublished observations, strains containing up to 10 and 11 plasmids respectively have been shown to frequently occur in natural populations. Therefore the Sym plasmid pool could well be large. Multiple Sym plasmids are likely to be prevalent if there is a significant degree of transfer of these plasmids between strains, such as that reported by Johnston et al. (1978). Exchange of Sym plasmids under natural conditions has been suggested by Schofield et al. (1987).

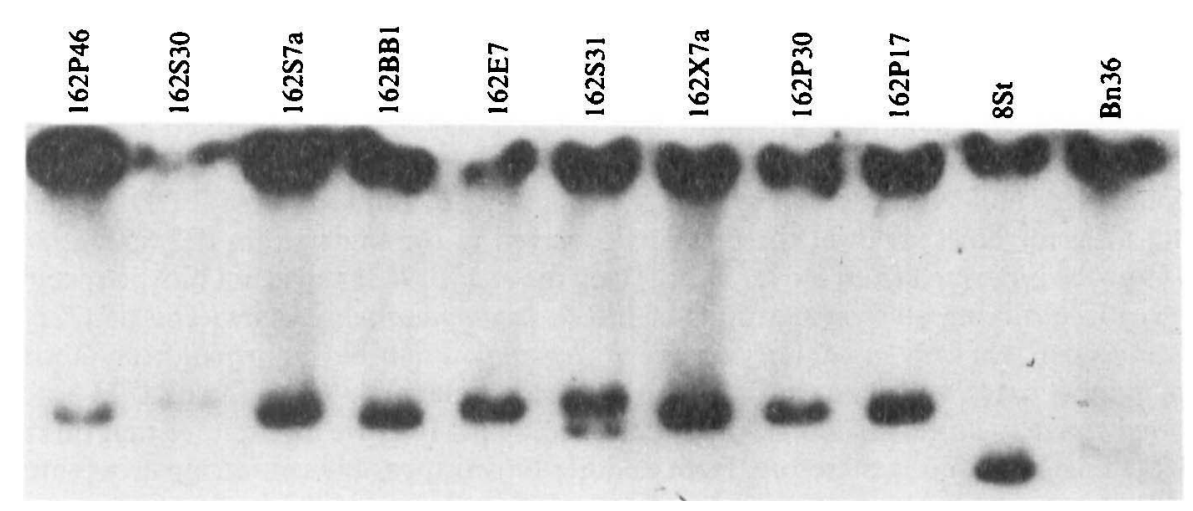

Fig. 1. Sym plasmid variation indicated by hybridization with pIJ 1085 . 
(a)

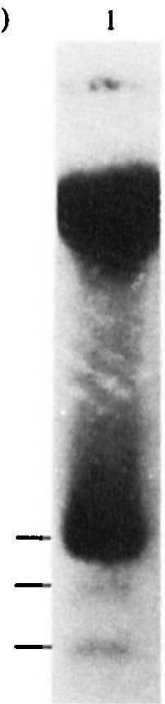

2

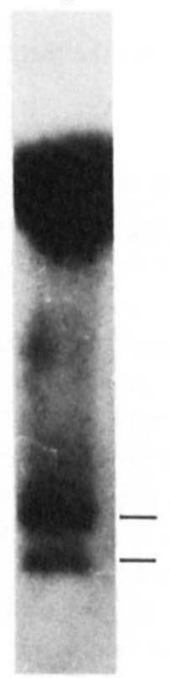

(b)

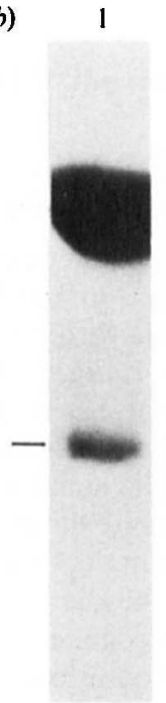

2

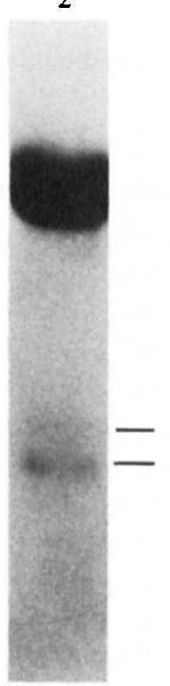

(c) 1 2

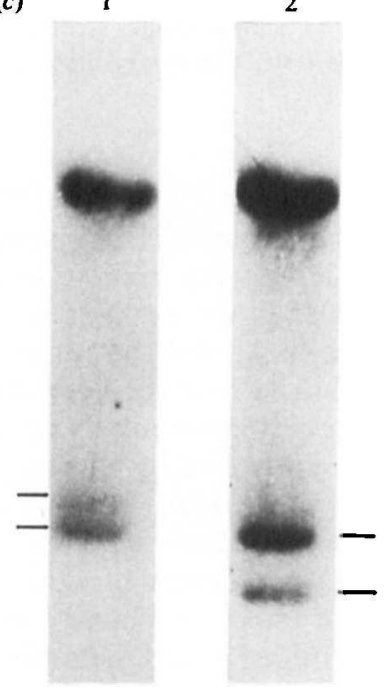

Fig. 2. Indication of symbiotic material using two different probes: lane 1 DNA was probed with pIJ1085 and lane 2 DNA with pRt722. The hybridizing plasmids are emphasized by the markers at the side of each lane. Strain C50 (a) shows two co-hybridizing plasmids and one extra plasmid binding to pIJ1085. Strain PDDCC $2669(b)$ has an extra plasmid binding to pRt722. The phenomena seen in (a) and $(b)$ can occur in the same strain: the isolate B2/8 $(c)$ contains one co-hybridizing plasmid and an extra plasmid binding both to pIJ 1085 and to pRt722.

The absence of a negative correlation between the size of Sym plasmids and the number of Sym plasmids suggests that multiple hybridization of pIJ1085 to plasmids is not a result of Sym plasmid cleavage. Similarly, the relative sizes of multiple Sym plasmids suggested that they were not multimers of one another. Deletion and co-integration arising as a result of interactions between multiple Sym plasmids such as those described by Djordevic et al. (1982), Christensen \& Schubert (1983), and Wang et al. (1986) may occur. Homologous recombination between Sym plasmids, as indicated by Schofield et al. (1987), is also likely, possibly resulting in reiteration of symbiotic genes on one of them.

\section{Variation in plasmid homology to pIJ1085 and pRt722}

The pRt722 plasmid is related to the RtRS plasmids used by Watson \& Schofield (1985) and contains DNA unique to the $R$. leguminosarum biovar trifolii Sym plasmid. Because of this, one would expect it to hybridize to plasmids also hybridizing to pIJ1085 within the biovar trifolii strains examined here. It could, therefore, by virtue of absence of hybridization, be used to identify Sym plasmids of non-trifolii origin in strains containing multiple Sym plasmids. In each strain at least one plasmid homologous to pIJ1085 also co-hybridized with pRt722 and in most cases where multiple Sym plasmids were identified by pIJ1085, all of them co-hybridized with pRt722. There were, however, a number of exceptions. Isolates were identified in which plasmids that bound to pIJ1085 did not bind to pRt722 (C50, Fig. 2a) and vice versa (PDDCC 2669, Fig. $2 b$ ) and, in some cases, both of these events occurred in the same strain (B2/8, Fig. 2c). The pIJ1085 probe is derived from biovar viceae (Downie et al., 1983) and is not biovar-specific. It is capable of identifying all Sym plasmids of the $R$. leguminosarum species. The pRt722 probe, however, is capable only of identifying the $R$. leguminosarum biovar trifolii promoter region, which, in most cases, suffices to indicate the trifolii Sym plasmid. When the pRt722 probe does not co-hybridize to an extra Sym plasmid identified by pIJ1085 we might infer that this is not a trifolii Sym plasmid and is therefore, from another biovar, possibly conferring cross-infectivity upon the strain (the chances of it having deletions for all copies of the repeated sequence are small). Conversely, if the reverse holds and only pRt722 binds to a plasmid this cannot be 
Table 3. Size of restriction fragments homologous to pRt 722

\begin{tabular}{|c|c|}
\hline Strain & Size of fragment $(\mathrm{kb})$ \\
\hline 2669 & $7 \cdot 5,4 \cdot 8,4 \cdot 0,3 \cdot 6,2 \cdot 9,1 \cdot 0,0 \cdot 3$ \\
\hline 2641 & $5 \cdot 0,4 \cdot 8,3 \cdot 6,2 \cdot 9$ \\
\hline 5065 & $4 \cdot 8,3 \cdot 6$ \\
\hline 4337 & $6 \cdot 6,5 \cdot 4,4 \cdot 8,3 \cdot 6,2 \cdot 9$ \\
\hline 2163 & $4 \cdot 8,3 \cdot 6,2.9$ \\
\hline 2118 & $11 \cdot 8,4 \cdot 8,3 \cdot 6,2 \cdot 9$ \\
\hline $162 S 7 a$ & $8 \cdot 0,4 \cdot 8,2.9$ \\
\hline $162 \mathrm{P} 17$ & $9 \cdot 6,5 \cdot 7,4 \cdot 8,2 \cdot 9$ \\
\hline $162 \mathrm{E} 7$ & $4 \cdot 8,3 \cdot 6,2 \cdot 9$ \\
\hline $162 \mathrm{P} 30$ & $7 \cdot 5,6 \cdot 3,4 \cdot 8,2 \cdot 9$ \\
\hline $162 \times 7 a$ & $7 \cdot 5,6 \cdot 3,4 \cdot 8$ \\
\hline $162 \mathrm{~S} 30$ & $9 \cdot 8,4 \cdot 8,3 \cdot 6$ \\
\hline $162 S 31$ & $4 \cdot 8,3 \cdot 6,2 \cdot 9$ \\
\hline 162BB1 & $7 \cdot 9,6 \cdot 8,4 \cdot 8,3 \cdot 6,2 \cdot 9$ \\
\hline $162 \mathrm{P} 46$ & $11 \cdot 8,9 \cdot 8,4 \cdot 8,2 \cdot 9$ \\
\hline $8 \mathrm{St}$ & $4 \cdot 9,3 \cdot 6,2 \cdot 9$ \\
\hline HAL/A3 & $6 \cdot 4,5 \cdot 2,4 \cdot 8,3 \cdot 8,2 \cdot 9,0 \cdot 4$ \\
\hline HAL/A7 & $4.8,2.9$ \\
\hline HAL/B5 & $16 \cdot 9,10 \cdot 5,8 \cdot 6,7 \cdot 5,5 \cdot 4,4 \cdot 8,4 \cdot 1,2 \cdot 9,1 \cdot 2,0 \cdot 4$ \\
\hline HAL/B9 & $16 \cdot 9,10 \cdot 5,8 \cdot 6,7 \cdot 5,5 \cdot 4,4 \cdot 8,4 \cdot 1,2 \cdot 9,1 \cdot 2,0 \cdot 4$ \\
\hline $\mathrm{HAL} / \mathrm{B} 16$ & $16 \cdot 9,10 \cdot 5,8 \cdot 6,7 \cdot 5,5 \cdot 4,4 \cdot 8,4 \cdot 1,2 \cdot 9,1 \cdot 2,0 \cdot 4$ \\
\hline HAL/B41 & $13 \cdot 8,9 \cdot 8,7 \cdot 8,6 \cdot 9,5 \cdot 9,5 \cdot 0,4 \cdot 8,3 \cdot 7,3 \cdot 1,1 \cdot 1,0 \cdot 4$ \\
\hline HAL/D11 & $10 \cdot 5,7 \cdot 5,5 \cdot 6,4 \cdot 8,3 \cdot 8,2 \cdot 9$ \\
\hline HAL/E14 & $5 \cdot 2,4 \cdot 8,3 \cdot 8,0 \cdot 4$ \\
\hline
\end{tabular}

deemed to be a totally functional Sym plasmid and can, at best, only be a related or deleted Sym plasmid. As these plasmids are always smaller than the co-hybridizing Sym plasmid, and since the occurrence of multiple Sym plasmids is not uncommon and they cannot be excluded as being Sym plasmids by virtue of the fact that the appearance of multiples is rare, it is feasible to suggest that they may contain deletions. In this respect, the findings are similar to those of Better et al. (1983) who, unlike Watson \& Schofield (1985), found copies of species-specific repeated sequences on two plasmids, one not being the Sym plasmid. Our findings may not contradict those of Watson \& Schofield (1985) since, in the majority of cases, plasmids hybridizing with pRt 722 also co-hybridize with pIJ1085 and those that do not co-hybridize could be a deleted Sym plasmid. However, it needs to be pointed out that our sample size was considerably larger than that of Watson \& Schofield (1985) and the chances of picking up hybridization of this RtRS with a non-Sym plasmid were greater.

\section{DNA restriction enzyme fragment polymorphism}

The RtRS probe was also used to analyse DNA restriction enzyme fragment polymorphism. Watson \& Schofield (1985), using similar probes, showed that characteristic hybridizing patterns existed for individual strains. Our results indicated the presence of between 2 and 11 fragments per strain ranging between 0.3 and $16.9 \mathrm{~kb}$ in size (Table 3). Three different-sized fragments of $4.8,3.6$, and $2.9 \mathrm{~kb}$ occurred frequently and were observed in 23,11 , and 19 strains respectively. In three cases, strains of different plasmid profile and origin $(2163,162 \mathrm{E} 7$, and 162S31) showed these hybridizing fragments only. This, together with the observations that at least two of these fragments occurred in all strains and all three occurred in seven strains, indicates a remarkable, basic relatedness between symbiotic DNA of biovar trifolii strains of diverse origin and genotype. The commonly occurring fragment, which by our estimations was $4.8 \mathrm{~kb}$ in size, could correspond to the $4.9 \mathrm{~kb}$ fragment containing the nifHDK genes already described by Schofield et al. (1983) and Watson \& Schofield (1985). This further emphasizes the high degree of intra-biovar relatedness. The appearance of this co-migrating fragment is similar to the situation in $R$. meliloti (Better et al., 1983) where three copies of a repeated sequence, located near the nitrogenase genes, were shown to be conserved on identically-sized fragments in 
ten out of eleven strains. Although this degree of consistency was apparent, the sizes of additional hybridizing fragments were more variable, conferring, for the most part, individual patterns on different strains. Apart from those isolates already mentioned, where digest patterns were shown to be the same, the plasmid profiles were also identical. Conversely, having the same plasmid profile did not necessarily indicate equivalent restriction fragment polymorphism, as shown by the relationships between $162 \mathrm{~S} 30$ and $162 \mathrm{~S} 31$ and between 162P17 and 162P30. The observation of fragments occurring in addition to the constantly occurring fragments suggests that these pieces of DNA are unstable, perhaps due to an ability to promote recombination and deletion. However, Watson \& Schofield (1985) indicated that these RtRS were not transposable, as does their recurrence on the $4.8 \mathrm{~kb}$ fragment. Supporting this is the absence of these sequences from the Sym plasmids of other biovars, despite the possible occurrence of hybrid strains where multiple Sym plasmids would have the opportunity to exchange DNA. For immediate analysis of freshly isolated indigenous strains during population studies, comparisons of restriction fragment length polymorphisms could lend a certain degree of precision in distinguishing between closely related strains although caution must be observed if it is to be used for long-term studies, e.g. soil inoculum studies or work involving prolonged storage of cultures.

The number of fragments hybridizing with the pRt722 probe is significantly correlated with the number of plasmids that hybridize $(r=0.770 ; P<0.001)$. This might be expected since the presence of extra plasmids carrying this symbiotic DNA would increase the potential number of restriction fragments containing this genetic material. Predictably, therefore, the number of hybridizing fragments is also correlated strongly with the number of Sym plasmids $(r=0.734$; $P<0.001)$ and also the total number of plasmids $(r=0.784 ; P<0.001)$.

\section{Relationship between the amount of symbiotic DNA and the effectiveness of nitrogen fixation}

The mean dry weights of white clover plants inoculated with the various strains tested are given in Table 4. Confirming the work of Thurman et al. (1985), we found a negative correlation $(r=-0.612 ; P<0.001)$ between the total number of plasmids and dry weight of plants. The number of Sym plasmids was also observed to be negatively correlated with dry weight $(r=-0.561 ; P<0.001)$. As the total number of plasmids is positively associated with the number of Sym plasmids it is suggested that the negative relationship between the total plasmid count and dry weight is, in fact, a function of Sym plasmid number. An absence of a significant negative correlation of plasmid number with dry weight, excluding strains with more than one Sym plasmid from the calculation, lends support to this theory.

It would appear, therefore that a strain may have an excess of symbiotic genetic material: This is emphasized by the negative correlation of the number of plasmids hybridizing with pRt722 with dry weight $(r=-0.553 ; P<0.001)$.

A further point emphasizing these negative effects is that the number of hybridizing restriction fragments is also negatively correlated $(r=-0.565 ; P<0.001)$ with dry weight. However, as the number of hybridizing fragments is correlated with the number of Sym plasmids and pRt722-hybridizing plasmids, the negative association could again be a function of total nif genetic material. As the negative correlation between fragment number and dry weight (excluding multiple Sym and pRt722-binding plasmid strains from the calculation) is non-significant $(r=-0 \cdot 317 ; P>0 \cdot 1)$, this is feasible.

It is difficult to state which factor causes the negative correlation, be it the mass of total symbiotic DNA, something carried on it, or interactions between the repeated sequences. Competition possibly occurs for metabolites or gene products in strains that have multiple Sym plasmids which, in essence, may be 'polyploid' for particular symbiotic genes.

Examination of size, number and host specificity of Sym plasmids in these isolates suggests that the potential for recombination and transference of Sym plasmids is high. The wide variability in RtRS restriction fragment polymorphism is also indicative of a high degree of Sym plasmid recombination, although a basic relatedness between strains is apparent. The possession, in a single strain, of large amounts of symbiotic DNA available to generate such variation does not result in enhanced nitrogen fixation and it would appear that there is an 
Table 4. Summary of the genetic variability of symbiotic DNA in strains tested for effectiveness of nitrogen fixation

\begin{tabular}{|c|c|c|c|c|}
\hline Strain & $\begin{array}{l}\text { No. of RtRS } \\
\text { fragments }\end{array}$ & $\begin{array}{l}\text { No. of Sym } \\
\text { plasmids }\end{array}$ & $\begin{array}{l}\text { Size of Sym } \\
\text { plasmid (kb) }\end{array}$ & $\begin{array}{c}\text { Dry wt* } \\
\text { (mg per plant) }\end{array}$ \\
\hline 2668 & ND & 1 & 188 & $15 \cdot 61 \pm 0 \cdot 60$ \\
\hline $162 \times 7 a$ & 3 & 1 & 219 & $13.77 \pm 0.68$ \\
\hline 2163 & 3 & 1 & 147 & $13.65 \pm 0.32$ \\
\hline 2641 & 4 & 1 & 171 & $12.94 \pm 0.68$ \\
\hline $8 \mathrm{St}$ & 3 & 1 & 111 & $12.67 \pm 0.69$ \\
\hline $162 \mathrm{P} 46$ & 4 & 1 & 188 & $11.82 \pm 0.55$ \\
\hline $\mathrm{HAL} / \mathrm{A} 3$ & 6 & 1 & 171 & $11.48 \pm 0.43$ \\
\hline HAL/A7 & 2 & 1 & 356 & $11.28 \pm 0.62$ \\
\hline $162 \mathrm{Pl} 17$ & 4 & 1 & 219 & $11 \cdot 16 \pm 0.50$ \\
\hline HAL/D10 & ND & 1 & 171 & $10.91 \pm 0.40$ \\
\hline $162 S 30$ & 3 & 1 & 238 & $10.60 \pm 0.29$ \\
\hline $162 \mathrm{P} 30$ & 4 & 1 & 219 & $10.33 \pm 0.43$ \\
\hline 162BB1 & 5 & 1 & 188 & $10.30 \pm 0.42$ \\
\hline HAL/E11 & ND & 1 & 238 & $10.09 \pm 0.39$ \\
\hline HAL/E14 & 4 & 1 & 219 & $9.31 \pm 0.40$ \\
\hline $162 \mathrm{E} 7$ & 3 & 1 & 219 & $9 \cdot 22 \pm 0.27$ \\
\hline 2669 & 7 & i & 238 & $8.67 \pm 0.37$ \\
\hline 2666 & ND & 1 & 188 & $8.36 \pm 0.52$ \\
\hline $16257 \mathrm{a}$ & 3 & 1 & 188 & $8.22 \pm 0.45$ \\
\hline Bn36 & ND & 2 & 256,159 & $8 \cdot 16 \pm 0.34$ \\
\hline 2153 & ND & 1 & 188 & $8.13 \pm 0.51$ \\
\hline $162 S 31$ & 3 & 2 & 238,159 & $8.09 \pm 0.48$ \\
\hline 2118 & 4 & 1 & 313 & $7.75 \pm 0.41$ \\
\hline HAL/B4l & 11 & 2 & 171,119 & $7.58 \pm 0.39$ \\
\hline 1306 & ND & 1 & 256 & $6.66 \pm 0.40$ \\
\hline $\mathrm{HAL} / \mathrm{B} 9$ & 10 & 2 & 219,147 & $6.35 \pm 0.37$ \\
\hline HAL/D11 & 6 & 2 & 219,134 & $5.77 \pm 0.35$ \\
\hline 5065 & 2 & 1 & 313 & $5.69 \pm 0.39$ \\
\hline 4337 & 5 & 1 & 171 & $5.38 \pm 0.42$ \\
\hline HAL/B5 & 10 & 2 & 219,147 & $4.61 \pm 0.39$ \\
\hline $\mathrm{HAL} / \mathrm{B} 16$ & 10 & 2 & 219,147 & $4.14 \pm 0.33$ \\
\hline
\end{tabular}

ND, Not determined.

* Values are the mean \pm SE of twenty plants.

optimal amount of symbiotic DNA either in terms of total mass or in the number of genes present.

During this work S.P.H. was supported by a CASE studentship award from the Science and Engineering Research Council and P.H.D.S. by a research student grant from the Ministry of Agriculture, Fisheries and Food. We wish to thank R. Stewart-Smith (The Nitragin Co., Milwaukee), J. M. Young (DSIR, Auckland), A. Squartini (Universita di Padova) and H. Mohd Saud (UCW, Aberystwyth) for their Rhizobium contributions, J. M. Watson (CSIRO, Canberra) for kindly supplying us with pRt722, and D. J. Hopper (UCW, Aberystwyth), C. I. Kado (University of California, Davis) and M. Jobling (University of Liverpool) for plasmid standards.

\section{REFERENCES}

Better, M., Lewis, B., Corbin, D., DitTA, G. \& HelinsKI, D. R. (1983). Structural relationships among Rhizobium meliloti symbiotic promoters. Cell 35, 479-485.

Brewin, N. J., DeJong, T. M., Phillips, D. A. \& Johnston, A. W. B. (1980). Co-transfer of determinants for hydrogenase activity and nodulation ability in Rhizobium leguminosarum. Nature, London 288, 77-79.

Christensen, A. H. \& SCHUbert, K. R. (1983). Identification of a Rhizobium trifolii plasmid coding for nitrogen fixation and nodulation genes and its interaction with pJB5JI, a Rhizobium leguminosarum plasmid. Journal of Bacteriology 156, 592-599.

DJORDEVIC, M. A., ZuRKowski, W. \& Rolfe, B. G. (1982). Plasmids and stability of symbiotic properties in Rhizobium trifolii. Journal of Bacteriology 151, $560-568$. 
Downie, J. A., MA, Q. S., KNIGHT, C. D., НомBRECHER, G. \& Johnston, A. W. B. (1983). Cloning of the symbiotic region of Rhizobium leguminosarum: the nodulation genes are between the nitrogenase genes and a nif $A$-like gene. EMBO Journal 2, 947952.

ECKHARDT, T. (1978). A rapid method for the identification of plasmid deoxyribonucleic acid in bacteria. Plasmid 1, 584-588.

Gotz, R., Evans, I. J., Downie, J. A. \& Johnston, A. W. B. (1985). Identification of the host range DNA which allows Rhizobium leguminosarum strain TOM to nodulate cv. Afghanistan peas. Molecular and General Genetics 201, 296-300.

Hirsch, P. R., van Montagu, M., Johnston, A. W. B., BrewiN, N. J. \& Schell, J. (1980). Physical identification of bacteriocinogenic, nodulation and other plasmids in strains of Rhizobium leguminosarum. Journal of General Microbiology 120, 403-412.

HOMBreCHER, G., BREWIN, N. J. \& JohNSTON, A. W. B. (1981). Linkage of genes for nitrogenase and nodulation ability on plasmids in Rhizobium leguminosarum and $R$. phaseoli. Molecular and General Genetics 182, 133-136.

HooykaAs, P. J. J., van BRussel, A. A. N., Den DulKRAS, H., VAN SLOGTEREN, G. M. S. \& SCHILPEROORT, R. A. (1981). Sym plasmid of Rhizobium trifolii expressed in different rhizobial species and Agrobacterium tumefaciens. Nature, London 291, 351353.

JENSEN, H. L. (1942). Nitrogen fixation in leguminous plants I. General characters of root nodule bacteria isolated from species of Medicago and Trifolium in Australia. Proceedings of the Linnean Society of New South Wales 66, 98-108.

Johnston, A. W. B., Beynon, J. L., BuchananWollaston, A. V., Setchell, S. M., Hirsch, P. R. \& BERINGER, J. E. (1978). High frequency transfer of nodulating ability between strains and species of Rhizobium. Nature, London 276, 634-636.

JORDAN, D. C. (1984). Family III. Rhizobiaceae. In Bergey's Manual of Systematic Bacteriology, vol. 1, pp. 234-256. Edited by N. R. Krieg. Baltimore \& London: Williams \& Wilkins.

Krol, A. J. M., Hontelez, J. G. J. \& VAN Kammen, A. (1982). Only one of the large plasmids in Rhizobium leguminosarum strain PRE is strongly expressed in the endosymbiotic state. Journal of General Microbiology 128, 1839-1847. van LaRebeke, N., Engler, G., Holsters, M. vaN DEN ElSACKer, S., ZAENEN, I., SCHILPEROORT, R. A. \& SCHELL, J. (1974). A large plasmid in Agrobacterium tumefaciens essential for crown-gall inducing ability. Nature, London 252, 169-170.

Norrander, J., Kempe, T. \& Messing, J. (1983). Construction of improved M13 vectors using oligonucleotide-directed mutagenesis. Gene 26, 101-106.

Nuti, M. P., Lepidi, A. A., Prakash, R. K., SChIlperoort, R. A. \& CANNON, F. C. (1979). Evidence of nitrogen fixation (nif) genes on indigenous Rhizobium plasmids. Nature, London 282, 533-535.

Ronson, C. W. \& ScotT, D. B. (1983). Identification, broad host range mobilization and mutagenesis of a Rhizobium trifolii Sym : : $\mathbf{R 6 8 . 4 5}$ cointegrate plasmid. In Molecular Genetics of Bacteria-Plant Interaction, pp. 177-187. Edited by A. Puhler. Berlin \& Heidelberg : Springer.

RuVkun, G. B. \& AUsubel, F. M. (1980). Interspecies homology of nitrogenase genes. Proceedings of the National Academy of Sciences of the United States of America 77, 191-195.

SCHOFIELd, P. R., DJoRdevic, M. A., Rolfe, B. G., Shine, J. \& WATSON, J. M. (1983). A molecular linkage map of nitrogenase and nodulation genes in Rhizobium trifolii. Molecular and General Genetics 192, 459-465.

Schofield, P. R., Gibson, A. H., Dudman, W. F. \& WATSON, J. M. (1987). Evidence for genetic exchange and recombination of Rhizobium symbiotic plasmids in a soil population. Applied and Environmental Microbiology 53, 2942-2947.

ScotT, K. F., Rolfe, B. G. \& ShINe, J. (1983). Biological nitrogen fixation: primary structure of the Rhizobium trifolii iron protein gene. DNA 2, 149-155.

Thurman, N. P., LewIS, D. M. \& JoNEs, D. G. (1985). The relationship of plasmid number to growth, acid tolerance and symbiotic efficiency in isolates of Rhizobium trifolii. Journal of Applied Bacteriology 58, 1-6.

WANG, C. L., HiRsCh, P. R. \& BeringeR, J. E. (1986). Host plant effects on hybrids of Rhizobium leguminosarum biovars viceae and trifolii. Journal of General Microbiology 132, 2063-2070.

Watson, J. M. \& Schofield, P. R. (1985). Speciesspecific, symbiotic plasmid located repeated DNA sequences in Rhizobium trifolii. Molecular and General Genetics 199, 279-289.

ZURhOWSKI, W. (1982). Molecular mechanism for loss of nodulation properties of Rhizobium trifolii. Journal of Bacteriology 150, 999-1007. 